\title{
Mothers' perceptions of educational access and engagement in a context of urban austerity
}

\author{
Amy Krings ${ }^{\mathrm{a}, *}$, Hillary Thomas ${ }^{\mathrm{a}}$, Shawna J. Lee ${ }^{\mathrm{b}}$, Aayat Ali ${ }^{\mathrm{b}}$, LaDonna Miller ${ }^{\mathrm{a}}$ \\ a School of Social Work, Loyola University Chicago, Chicago, IL, United States \\ ${ }^{\mathrm{b}}$ School of Social Work, University of Michigan, Ann Arbor, MI, United States
}

\section{A R T I C L E I N F O}

\section{Keywords:}

Educational justice

Parent participation

Focus group methodology

Detroit, Michigan

Emergency management

Social policy

Public policy

\begin{abstract}
A B S T R A C T
This study sheds light upon mothers' perceptions of educational justice in a context of austerity-based educational reforms. Focus group participants $(n=64)$ described local schools as lacking resources, a shortcoming that contributed to overcrowded classrooms, inadequate transportation, and safety concerns. They were skeptical of elected and appointed state and district officials, who were viewed as misrepresenting the degree of financial strain in the district in order to prioritize financial profit above education services for children. Additionally, respondents struggled to identify opportunities for parent involvement in educational policy making at a state, district, or school level. The shortage of resources, skepticism, and lack of opportunity culminated in what were often described as contentious relationships between parents and school officials. Our results suggest that mothers recognize that they have been disenfranchised as a result of educational reforms. They are more likely to enroll their children and participate in schools when they perceive that there are adequate resources, that children's needs are prioritized above fiscal austerity, and that their opinions are valued.
\end{abstract}

\section{Introduction}

This study examines the perceptions of parents, most of whom were African American or Latina mothers whose children attended school in Detroit, Michigan to shed light on issues of educational justice and equity in the city. Specifically, we report findings from six focus groups that examined what were perceived to be root causes and potential solutions related to educational improvement in the Detroit. We also asked about perceptions of statewide educational reforms that were implemented in Michigan during the last decade and their impacts on parents' access to resources, decision-making venues, and quality schools. To capture the ideas of parents whose children attended Detroit Public Schools (DPS), as well as those whose children lived in the city but were not enrolled in public schools, focus groups were held in two public schools, a charter school, a private religious school, and a state-controlled school.

Participants told us that they were concerned that the Detroit Public School system lacks access to resources, particularly investments that promote a quality learning environment. Parents were skeptical that the district budget situation was as dire as officials reported. Additionally, parents were unsatisfied with their ability to access decision-making venues, including those related to school and district-wide budgets.
These limited resources and opportunities for meaningful local participation resulted in relationships that were often characterized as adversarial between parents and district or state officials. These themes suggest that urban educational reforms are more likely to result in increased enrollments and strong school-community relationships if they include equitable investments, increased transparency regarding budgeting, and opportunities for collective local decision-making.

\subsection{Educational inequality}

Quality education contributes to healthy youth and communities (Center on Society and Health, 2014). However, educational inequality exists in the United States with disproportionate impacts on people who live in school districts that are predominantly poor and Black or Latino (Aud et al., 2011; Darling-Hammond, 1998). These inequalities result from a complex history that includes school and residential segregation, racial injustice, and property-tax-based local funding of public schools (Macedo, 2003; Reed, 2001). For example, state and federal agencies contributed to the decline of urban areas, including urban school districts, through exclusionary zoning, policies that prioritized highway construction over public transit, housing policies that favored singlefamily over multifamily dwellings, and the use of redlining to guarantee

\footnotetext{
Abbreviations: DPS, Detroit Public Schools; EAA, Education Achievement Authority

* Corresponding author at: School of Social Work, Loyola University Chicago, 820 N. Michigan, Chicago, IL 60611, United States.

E-mail address: akrings@luc.edu (A. Krings).
} 
mortgages in racially homogenous (i.e., White) suburban communities (Burns, 1994; Reed, 2001; Sugrue, 2005). These policies led to reduced public revenues as residents left and property taxes declined. Thus, at the same time that municipalities and school districts lost income, there was a greater concentration of social need (Reed, 2001). These broad factors continue to contribute to urban school districts' struggles to meet basic needs such as paying teachers, purchasing supplies, maintaining buildings, and investing in extracurricular activities as compared with well-off suburban districts that enjoy greater resources and less concentration of need (Macedo, 2003). The culmination of these historic and structural factors reduces the ability of many poor and Black or Latino parents to access quality public schools for their children.

\subsection{Logic of educational justice}

Nygreen (2016) compares paradigms of educational justice that seek to explain and address educational inequity. The most dominant is the neoliberal paradigm, an ideological system as well as a set of political-economic policies that favor the application of market-based principles to all aspects of public life, including education and social services (Harvey, 2005). The logic of neoliberalism suggests that infusing market competition will improve school quality because parents, who in this model can act as consumers, will choose the best school for their children. In this way, the market will "reward" excellent schools with students and the funding that comes with them and it will eliminate failing schools. The logic of neoliberalism also manifests through decision-making structures in which technocratic "experts" make decisions without the infusion of politics, and thereby with limited democratic accountability. Neoliberal principles are embedded within educational policies such as the privatization of educational services, increased reliance on standardized testing, introduction of incentives and sanctions for schools, promotion of school competition, and dismantling of organized labor such as teachers' unions (Nygreen, 2016).

Nygreen (2016) suggests that the neoliberal paradigm differs from a community-based parent organizing logic in terms of how root causes are defined, how parents engage, and what solutions are deemed viable. In contrast to neoliberal logic, the parent organizing approach suggests that systemic injustice is the root cause of educational inequality. This model posits that parent participation in democratic governance and self-determination is necessary to advance educational justice. Consequently, the parent organizing model views parents as experts whose input into educational reforms is valued; this contradicts the neoliberal reliance upon top-down technocratic decision making and parent engagement as consumers.

\subsection{Educational reforms in a neoliberal context}

In Michigan, a logic of neoliberalism is apparent within two important educational reforms: emergency management and the creation of a state-run school district in Detroit. The emergency management law permits state officials to appoint a receiver, known as an emergency manager, whose job is to balance the budget when a city or school district cannot meet its financial obligations (Anderson, 2012; Loh, 2016; Scorsone, 2014). Although emergency managers are charged with balancing the budget, they may not raise taxes nor renegotiate with creditors. In this way, they are incentivized to eliminate or privatize public services, sell off assets such as public land and buildings, and renegotiate collective bargaining contracts. Emergency managers are able to do this without the consent of elected bodies such as school boards, leading some critics to describe the policy as undemocratic (Anderson, 2012; Loh, 2016). Overall, the policy codifies the transfer of political power away from elected school boards, parent groups, and teachers' unions.

Emergency management has also been critiqued as a policy that unfairly burdens the poor and racial or ethnic minorities. Peck (2012) noted that required cuts in services are geographically bound within cities and school districts, even though the roots of budget deficits emerged, at least in part, within state, national, and even international political and economic decisions that were made outside the control of residents. Furthermore, there are significant racial disparities in the implementation of emergency management laws in Michigan. Between 2008 and $2013,51 \%$ of African American, $16.6 \%$ of Latino, and only $2.4 \%$ of White residents in Michigan lived in cities that were governed by an emergency manager (Lee et al., 2016). The Detroit Public School District was under state control through emergency management from 1999 to 2005 and again from 2009 to 2016 (Zaniewski, 2015).

Another contemporary and controversial educational reform in Michigan was the establishment of a state-controlled school district, the Education Achievement Authority (EAA). In 2012, the EAA was established to take over and strengthen fifteen Detroit Public Schools that were deemed to be failing by state standards. However, the goal of turning around these schools was largely unmet. In the five years that the EAA was in place, the fifteen schools in the district went from an enrollment of 11,000 students to 6000 students and there were mixed results in terms of academic improvement (Higgins, 2017a). In addition to limited impacts in terms of educational outcomes among students in the EAA district, critics noted that DPS was economically disadvantaged because the district lost the per-pupil revenue associated with students (Hammer, 2011). On July 1, 2017, the EAA district was disbanded and its fifteen schools were reintegrated within the public school district.

\subsection{Study rationale: parent perceptions of educational quality}

While challenges relating to limited resources, competition from charter schools, and underperforming student outcomes are not unique to Detroit, the city may be one of the best known examples of an underperforming public school district in the United States. Research about the cause of these problems and their resolution has been examined (Hamlin, 2017; Hammer, 2011; Hula, Jelier, \& Schauer, 1997; Lee, Croninger, \& Smith, 1994; Mirel, Galston, \& Guthrie, 1999), but the perspectives of the families who are most affected has been neglected. Thus, the motivation for this study emerged from questions about how parents perceive and navigate the educational system in a context of urban austerity.

Our contribution is to analyze the perspectives of mothers who lived in the city of Detroit and who had direct experience with underperforming schools while the emergency management and EAA policies were in place. We sought to understand parents' ideas about what can and should be done to address substandard schools as well as their thoughts regarding the role of parent engagement. To this end, we interviewed African American and Hispanic/Latino mothers, recognizing that these groups have been disproportionately affected by policies related to poor schools such as the EAA system and emergency management.

This study examines the following questions: (1) How do parents whose children attend school in Detroit describe their education-related experiences? (2) How do parents interpret the role of institutional features (e.g., public, private, and charters) and educational policies (e.g., emergency management and the EAA) as facilitating or detracting from quality education for their children? (3) In what ways have parents sought to influence educational policies?

We used grounded theory to analyze the focus group data, which was informed by our desire to utilize a social justice perspective that provided space for the voices of parents to identify shared experiences and ideas regarding education and to propose potential solutions. Thus, the findings of the study have the potential to inform policy-makers regarding how parents perceive core challenges and potential solutions relating to educational improvement. 


\section{Research design and methods}

\subsection{Setting}

The city of Detroit has had to cope with numerous fiscal crises resulting from decades of declines in population, employment, tax revenues, and state revenue sharing. Many of these trends were driven by deindustrialization, racial segregation, and impoverishment through residential abandonment (Sugrue, 2005). The region of southeast Michigan, where Detroit is located, is one of the most racially and economically segregated areas in the country (Darden, Stokes, \& Thomas, 2007). In 2013, Detroit became the largest municipality in the United States to declare bankruptcy (Bomey \& Gallagher, 2013). The local school district, DPS, has also struggled: it has lost 130,000 students since 1999 with 46,000 students enrolled in 2017 (Higgins, 2017b). This decline in enrollment has been attributed to families moving out of the city as well as to the growth of charter schools. In Detroit, 53\% of students attend charter schools (National Alliance for Public Charter Schools, 2015). Consequently, as urban public schools must compete with charter and suburban districts for students-and the state dollars that are awarded on the basis of enrollment-their budgetary pressures have been exacerbated (Hammer, 2011).

Detroit Public Schools have also failed to provide consistently highquality education to students. In 2015, district score averages were the lowest across all math and reading benchmarks on the National Assessment of Educational Progress tests (given to fourth and eighth graders) compared to twenty-one other large urban districts or counties in the United States (National Assessment of Educational Progress, 2015). Within the state of Michigan, more than $75 \%$ of Detroit schools with available standardized testing data ranked below the tenth percentile (Michigan Department of Education, 2016).

This study included parents with children in various types of schools in Detroit including public, private, charter, and EAA state-run schools and focused upon the experiences of Black and Latino families, who are disproportionately impacted by austerity policies and educational cuts in the United States. Blacks and Latinos make up the majority of Detroit residents. According to the 2015 American Community Survey, $79 \%$ of Detroit residents identify as African American, $8 \%$ as Latino, and $10 \%$ as White (Census Reporter, 2015). However, despite our intention to recruit in a manner that reflected the Detroit population, our sample does not reflect the overall Detroit population with respect to race and ethnicity. Table 1 presents the basic characteristics of the five schools at which focus groups were conducted, with the name of the school removed. One of the two public elementary schools predominantly served Latino students (86\%) and the other consisted almost entirely of African

Table 1

School information, 2015-2016.

\begin{tabular}{clllll}
\hline Type of school & Public EAA & Public DPS & $\begin{array}{l}\text { Private } \\
\text { (Catholic) }\end{array}$ & Charter & Public DPS \\
\hline $\begin{array}{c}\text { Total } \\
\text { enroll- }\end{array}$ & 604 & 474 & 164 & 570 & 410 \\
$\begin{array}{c}\text { ment } \\
\text { Grade levels }\end{array}$ & $9-12$ & $\begin{array}{l}\text { Prekinder- } \\
\text { garten-8 }\end{array}$ & $\begin{array}{l}\text { Kinder- } \\
\text { garten-8 }\end{array}$ & $\begin{array}{l}\text { Kinder- } \\
\text { garten-8 }\end{array}$ & $\begin{array}{l}\text { Prekinder- } \\
\text { garten-5 }\end{array}$ \\
$\begin{array}{c}\text { Race or } \\
\text { ethnicity }\end{array}$ & & & & & \\
Black & $100 \%$ & $100 \%$ & $10 \%$ & $7 \%$ & $5 \%$ \\
$\quad \begin{array}{l}\text { Latino } \\
\text { White }\end{array}$ & & $0.2 \%$ & $81 \%$ & $92 \%$ & $86 \%$ \\
$\begin{array}{c}\text { Overall state } \\
\text { ranking }\end{array}$ & 0 & $0.2 \%$ & $9 \%$ & $1 \%$ & $7 \%$ \\
& & 1 & N/A & 43 & 18 \\
\end{tabular}

${ }^{a}$ Numbers are rounded to nearest $1 \%$ and therefore race/ethnicity totals do not equal $100 \%$.

${ }^{\mathrm{b}}$ Race and ethnicity and enrollment data were accessed online from the National Center for Education Statistics; state ranking data obtained online from the Michigan School Data website.
American students (rounded to $100 \%$ ). The charter and private schools predominantly served Latino students ( $86 \%$ and $81 \%$, respectively). The EAA high school served almost exclusively African American students (rounded to 100\%). However, because so many parents attended this group, parents were divided into two separate EAA focus groups, resulting in a total of six focus groups at five schools. It should be noted that many parents had children at multiple schools or had children who transferred between school types over time. Therefore, even if the focus group was held in a private school, for example, some respondents discussed their experiences with other institution types such as charter or public schools.

Table 1 also includes overall statewide percentiles for each focus group school in order to provide some context of school performance relative to state academic standards. State school performance ranking is determined by several factors, most significantly by student achievement and student improvement on standardized tests. If the school (e.g., a high school) graduates students, graduation rate is also including in the calculation for school performance ranking. Each of these components is averaged over two academic years. The EAA high school was ranked in the 0 percentile, one public elementary school in the 1st percentile, the other in the 18th percentile, and the charter school in the 43rd percentile. Data for the private elementary school were not available from the state rankings because private schools do not report such information. In 2016, challenges in the district were captured on Twitter and in national news after teachers posted images of rats, mold, and disrepair within classrooms and later held organized sick-outs to call attention to unsafe working and learning environments (DeVito, 2016; Pérez-Peña, 2016; Strauss, 2016).

\subsection{Parent recruitment and sample}

To recruit participants, we partnered with a local evaluation consultant who had established relationships with the schools and parent groups from which participants were recruited. The consultant is a White, native-born U.S. citizen with a master's degree in social work. These social characteristics and educational credentials, as well as her position as facilitator, conferred a position of power relative to the research participants. However, the research team selected her because she was bilingual, a long-term resident of Detroit whose children attended and graduated from schools in Detroit, and a trained facilitator of multiracial and bilingual focus groups. She conducted the groups with the assistance of an African American student intern with a master's degree in social work as well as training in facilitating focus groups.

Because we sought to include the perspectives of parents who preferred to speak in Spanish, we were prepared to conduct Spanish language focus groups in the three schools where $81 \%$ or more students identify as Latino (see Table 1). In these sessions, translation was offered in English and Spanish. The participants in the public elementary school opted to use only Spanish while those in the private school used only English; thus, no translation was necessary. The charter school was the only group that required real-time translation by the facilitator between English and Spanish.

Nearly all of the study participants were women; therefore, we refer to respondents as mothers throughout the article to more accurately describe the sample. Participants in our sample had children of all ages, ranging from toddlers to young adults who currently attend or previously attended school in Detroit, and many of the study respondents were graduates of the DPS system. Table 2 provides self-reported demographic data relating to our sample.

\subsection{Procedures}

The authors and the local consultant developed a semi-structured question guide to facilitate conversation around parents' perceptions of how educational policies including emergency management, the EAA, 
Table 2

Study participant characteristics.

\begin{tabular}{|c|c|c|c|c|c|c|}
\hline School type & Public EAA & Public DPS & Private Catholic & Charter & Public DPS & Total \\
\hline & $(n=18)$ & $(n=11)$ & $(n=9)$ & $(n=18)$ & $(n=8)$ & $(N=64)$ \\
\hline \multicolumn{7}{|l|}{ Variable (categories) } \\
\hline \multicolumn{7}{|l|}{ Gender } \\
\hline Female & $94.4 \%$ & $0.9 \%$ & $100.0 \%$ & $100 \%$ & $100 \%$ & $98.4 \%$ \\
\hline Male & $5.6 \%$ & & & & & $1.6 \%$ \\
\hline No reply & & $9.1 \%$ & & & & \\
\hline \multicolumn{7}{|l|}{ Race or ethnicity } \\
\hline African American & $94.4 \%$ & $90.9 \%$ & & & & $42.2 \%$ \\
\hline Hispanic & & & $88.9 \%$ & $88.9 \%$ & $100 \%$ & $50.0 \%$ \\
\hline White & & & $11.1 \%$ & & & $1.6 \%$ \\
\hline No reply & $5.6 \%$ & $9.1 \%$ & & $11.1 \%$ & & $6.3 \%$ \\
\hline \multicolumn{7}{|l|}{ Marital status } \\
\hline Single & $55.6 \%$ & $81.8 \%$ & $22.2 \%$ & $5.6 \%$ & $12.5 \%$ & $35.9 \%$ \\
\hline Married & $27.8 \%$ & $18.2 \%$ & $55.6 \%$ & $83.3 \%$ & $75.0 \%$ & $51.6 \%$ \\
\hline Other & $11.2 \%$ & & $11.1 \%$ & $11.2 \%$ & & $6.3 \%$ \\
\hline No reply & $5.6 \%$ & & $11.1 \%$ & $11.1 \%$ & $12.5 \%$ & $6.3 \%$ \\
\hline \multicolumn{7}{|l|}{ Educational level } \\
\hline Less than high school & $5.6 \%$ & $18.2 \%$ & $22.2 \%$ & $50.0 \%$ & $37.5 \%$ & $26.6 \%$ \\
\hline Diploma/GED & $38.6 \%$ & $45.5 \%$ & $11.1 \%$ & $22.2 \%$ & $25 \%$ & $29.7 \%$ \\
\hline Some college & $38.9 \%$ & 36.4 & $11.1 \%$ & $16.7 \%$ & $25.0 \%$ & $26.6 \%$ \\
\hline 4-Year degree & $11.1 \%$ & & $44.4 \%$ & & $12.5 \%$ & $12.5 \%$ \\
\hline No reply & $5.6 \%$ & & $11.1 \%$ & $11.1 \%$ & & $34.7 \%$ \\
\hline \multicolumn{7}{|l|}{ Income range } \\
\hline $0-\$ 29,999$ & $61.1 \%$ & $72.7 \%$ & $44.4 \%$ & $50.0 \%$ & $87.5 \%$ & $60.9 \%$ \\
\hline$\$ 30,000-\$ 39,000$ & $22.2 \%$ & $9.1 \%$ & $33.3 \%$ & $11.1 \%$ & $12.5 \%$ & $17.2 \%$ \\
\hline$\$ 40,000-\$ 49,999$ & $5.6 \%$ & & & $11.1 \%$ & & $4.7 \%$ \\
\hline \multicolumn{7}{|l|}{$\$ 50,000-\$ 59,999$} \\
\hline$\$ 60,000-\$ 69,999$ & $5.6 \%$ & & $11.1 \%$ & & & $3.1 \%$ \\
\hline$\$ 70,000-79,999$ & & & $11.1 \%$ & & & $1.6 \%$ \\
\hline No reply & $5.6 \%$ & $18.2 \%$ & & $27.8 \%$ & & $12.5 \%$ \\
\hline
\end{tabular}

and the opening and closing of schools in Detroit impact education quality and parent participation. The focus groups were facilitated in May, June, and July 2016. The average group size was 10.66 and one group had 18 participants. Two facilitators were present in each group; one facilitated the conversation while the other managed the audio recorder, sign-in sheet, incentive cards, and consent forms. At the EAA school, since the group was split in half due to the high number of participants, each group had one facilitator. Focus groups varied in length from 50 to $83 \mathrm{~min}$ and were audio recorded. A professional transcription company transcribed the focus group audio recordings and translated the Spanish language recordings into English. Later, a bilingual research team member listened to the audio recording in Spanish and compared it to the provided transcription to ensure accuracy.

When the focus groups began, the facilitator explained our protocol for the protection of human subjects in research, read the informed consent form aloud, and answered related questions before asking participants to sign informed consent forms. Part of the informed consent procedure included asking program participants to keep information that was shared confidential. Next, the facilitator requested that participants speak one at a time and only while holding the recorder so that everyone could be heard. All participants were asked to introduce themselves by giving their names and describing their relationship with schools in Detroit, particularly if and where their children attend school.

Introductions were followed by a series of questions to which group members could respond or remain silent. Topics included (1) how parents decided which schools were best for their children (how much "choice" was involved); (2) how parents perceive the educational quality in Detroit compared to ten years ago; (3) what parents think about the closure of public schools and growth of charter schools; (4) whether or not parents have heard of emergency management and the EAA and, if so, how they perceive these policies and their impact; (5) what sacrifices parents have made to ensure their children receive a quality education; (6) if and how parents have tried to improve their children's schools or the school system and how their efforts have been effective or limited; and (7) what they believe is necessary to transform Detroit schools to achieve their highest potential. After each focus group, participants received $\$ 50$ gift cards to thank them for their time.

\subsection{Data analysis}

Rooted in grounded theory, our data analysis process began with open coding of the six focus group transcripts (Emerson, Fretz, \& Shaw, 2011). Four coders read and open coded the focus group transcripts from the same three schools. The coders then met to discuss emerging themes that were identified as initial global codes. The themes included: (1) the presence or lack of school resources as an indicator of school quality, (2) the ways and extent to which parents engaged in their children's education and the school community, and (3) the quality of communication and trust between parents and schools. The coders then read through the next three focus group transcripts utilizing the global codes and memo writing for emerging themes that did not fit with initial codes. The coders came back together to discuss their results, identify new themes that emerged from the last three focus groups, integrate them with the global codes, and further revise the codebook to include subcodes. For example, the team added a fourth global code on transparency and access to district budgetary information.

With this final codebook, two of the coders read all six focus group transcripts a final time to identify quotes that illustrate all subcodes and to assess the extent to which the codebook captured key ideas discussed by parents across all six groups. These coders met once more to ensure consensus on our findings through iterative transcript reviews, coder debriefings, and memo writing. They also focused on data that challenged emerging themes, working to strengthen the dependability of 
Table 3

Participant quotes in English and in original Spanish with English translation.

\begin{tabular}{|c|c|c|}
\hline Themes & English language groups & Spanish language groups \\
\hline $\begin{array}{l}\text { 1. Parent perceptions of } \\
\text { quality learning } \\
\text { environment }\end{array}$ & $\begin{array}{l}\text { "If I got a test, I need a book so I can review what I'm doing } \\
\text { then. I need that homework sometimes. They don't even come } \\
\text { home with the homework half the time. So a lot of that they } \\
\text { could bring back and I think it would help. If not everything, } \\
\text { then definitely the books. Definitely the books. They need } \\
\text { that. They need that material." (EAA) } \\
\text { "I would like transportation for kids to tutoring. I have a } \\
\text { problem with my leg, and it's days that she misses because I } \\
\text { don't really have the support system as far as getting her } \\
\text { here." (Public) }\end{array}$ & $\begin{array}{l}\text { "No estaba aprendiendo, entonces por eso } \\
\text { lo cambié aquí, porque habia más pocito } \\
\text { niños, y allí entre más pocito niños en las } \\
\text { clase hay mayor atención y mayor } \\
\text { cuidado para que todos esten haciendo lo } \\
\text { que deben de hacer: su tarea" (Private) } \\
\text { (translation) He wasn't learning, so that's } \\
\text { why I changed him here, because there } \\
\text { were fewer children and the smaller the } \\
\text { class size, the more the attention and care } \\
\text { so that everyone is doing what they're } \\
\text { supposed to be doing; their work. }\end{array}$ \\
\hline
\end{tabular}

"Hoy que [mi hija], fue al colegio, ella dice...que mi hijo no estudie en las escuelas públicas de Detroit porque las escuelas están muy pobres en la área del Detroit. Ella no quiere que mi hijo llegue al colegio con menos conocimiento que todos...porque las escuelas están mejores en otras áreas." (Public)

(translation): "Now that [my daughter] is in college, she suggested that my son not go to the Detroit Public Schools because the schools in the Detroit area are poor. She doesn't want my son to get to college like she did, with less knowledge than everyone else ... because the schools are better in other areas."

2. Access to trustworthy "Everybody's stealing money—principals—everybody's doing budget information bad really. I can't really say what I want to say talking on this thing but it's really, really bad. And all our kids, with the exception of a few - the masses are losing out and the future is looking vague." (EAA)

3. Parent engagement and influence

4. Contentious relationships and lack of trust
Respondent 1: "I actually went to all the meetings, but there's no way to resist-you just get to speak your mind just like we're doing right now. In the end, they do what they want."

Respondent 2: "We voiced our opinion at meetings several times... but we had no power. And especially since the school board had no power, we didn't have any power too. We could voice our opinions, but nothing was changed."

Respondent 3: "I had my daughter in [public school] and teachers were striking and striking and striking. I took her out during that time."

Respondent 4: "We got to protest. I guess we have to protest." (EAA)

"Now, my feet swell up. I have heart problems as well. Sometimes I can't put on shoes, and [school administrators] wanna make it about, 'Oh, well, you know, you just need to get her here.' How? How? Believe me, I want my child to succeed!" (Public)
"Es bueno tener varias personas que están de acuerdo para la beneficia de todos, no solo de ellos, porque aquí lo que están dirigiendo es beneficios para ellos para ahorrarse mas que nada dinero. Porque lo que ellos esta haciendo es no pagarlo justo a las personas que están haciendo su desempeño que deben de hacer. Es el dinero más que nada que a ellos les está...Ah-ha ellos quieren ahorrarse." (Public)

(translation) It's good to have several people that agree to benefit everyone, not just themselves. Because [the emergency managers] are going to make decisions for their own benefit, to save money, because they aren't paying a fair salary to people who are performing. It's the money that will guide them — Ah-ha! They want to save money. "Todos queremos tener voz y voto para que nos escuchen. Más que nada por eso es lo que, sí, queremos, la mayoría...que nos cuenten. Pero por ciertos motivos, horarios, trabajos, o algo, no lo podemos a veces hacer." (Public)

(translation) We all want to be heard, at least that's what the majority of us want-to be heard and counted. But for whatever reason, timing, work, whatever, sometimes we just can't do it. "Cuando los maestros dicen, 'Apóyanos porque tenemos que ir a protestar, tenemos que apoyar a los maestros. No estoy de acuerdo con lo que esta pasando porque es la educación de nuestros hijos. Nos importa - bueno a mi, sí." (Charter) (translation) When the teachers say, 'Support us because we have to protest someplace,' we have to go support [them]. I don't agree with what's happening because it's our children's education. We care- at least I do.

"The ones who decide everything in the district and those who are in government, they need to realize that in Detroit there are many well-educated children who wish to continue learning. They think that in the Detroit area, people are poor so they aren't going to study. No! There are many children who want to study, but if there isn't enough education, how will they ever get ahead?" (Public)

(translation) Los que forman lo del districto y la gente del gobierno, que se den cuenta que en la área de Detroit hay muchos hijos capacitados que nosotros tenemos y que ellos quieren seguir estudiando. Que vean ellos, que nos enfoquen, porque en esa área de Detroit [creen] que la gente es pobre, no van a estudiar. No! Hay muchísimos muchachos que quieren estudiar, pero si no hay la suficiente educación, cómo van a seguir adelante? our findings.

\section{Findings}

In the following sections, we will present findings from respondents on the main themes that emerged from the discussion, including mothers' perceptions of a quality learning environment, access to reliable information, opportunities for participation, and relationships with school officials. Table 3 presents representative quotes for each theme from both the English and Spanish language focus groups, including the original Spanish and the English translation for those focus groups conducted in Spanish.

\subsection{Parent perceptions of a quality learning environment}

When parents described barriers to accessing quality education and when they shared ideas for improving schools, most stated that educational reform would not work without increased economic investments in students' learning environments. Specifically, they were skeptical that changes in district leadership or structure would matter without additional funding. Parents described the existing learning environment as lacking educational resources necessary to purchase materials (e.g., books), to pay teachers (which was necessary to prevent overcrowded classrooms), and to fund safe and reliable transportation services. Furthermore, they stated that these resources influence school safety as well as their decisions as parents regarding where to send their children to school.

School materials were described as a measure of a school's quality, and many parents interpreted a lack of resources as a consequence of racial or class prejudice. One mother whose children attended public and EAA schools with a majority of African American students stated that inadequate local investments reflect existing educational inequalities: 
If they don't have the materials and supplies and the resources they need, then they're going to be behind. ...They're always going to fall behind because they don't have the resources that [suburban or private] schools have.

Similarly, parents connected class prejudices to unequal distribution of material resources in schools. As one parent of a public school student described,

It's gotten worse because people have become very judgmental of the home. If you aren't in a certain class, they will not invest in you: "I don't have time to invest in you because I can't relate to you. I'll take from you to fill my pockets and you'll suffer, but that was your destiny anyway."

The lack of investment in educational materials was felt in the home as well as classrooms. For example, parents stated that having access to material resources are necessary create a positive learning environment at home. A parent whose child attended the EAA school said:

If I got a test, I need a book so I can review what I'm doing then. I need that homework sometimes. They don't even come home with the homework half the time. So a lot of that they could bring back and I think it would help. If not everything, then definitely the books. Definitely the books. They need that. They need that material.

Parents characterized divestment in material resources, which was perceived as closely tied to poorer academic outcomes for their children, as a worsening problem over the past decade. One mother highlighted the long-lasting impacts of educational inequality by explaining that her daughter, a DPS graduate and current university student, "suggested that my son not go to the Detroit Public Schools because the schools in the Detroit area are poor. She doesn't want my son to get to college like she did, with less knowledge than everyone else ... because the schools are better in other areas."

Parents perceived shortages of teachers as a key factor resulting in another problem within the school system, unmanageable class size. Parents connected large class sizes to behavior management issues and a lack of structure and safety, all of which negatively affect the learning environment. One mother, whose children attend a predominately Latino public high school, described how the combined impact of teacher and staff shortages, exacerbated by the lack of air conditioning and inadequate classroom accommodations, affected classroom functioning:

The problem was-the teachers there were good, but they were short on teachers so there were too many students to a single teacher ... there were 40 students to a single teacher, and the teacher would just give us a piece of paper with a word jumble and that was it. And it was so hot that the teachers would fall asleep in class due to the lack of air conditioning. Many students had to get into the benches sideways to sit down in the desks. They are short staffed in the schools, for the same reason, they don't get paid.

As a result, she transferred her children to a charter school.

Parents highlighted how teacher shortages and large class sizes impacted families at home. For example, parents in two focus groups associated overcrowded classrooms and proximity to other students with head lice. In the public school group, one mother identified head lice as prompting her to transfer her children to a private school. Other parents discussed how head lice also results in school absenteeism and the disruption of their family routine.

Multiple parents indicated that hiring more teachers was one important way to improve Detroit Public Schools. They also identified related priorities such as paying teachers more and ensuring that teachers were appropriately trained and certified. For example, one parent at a public elementary school described the tendency for charter schools to offer teaching positions to young Teach for America participants who have college degrees, but do not have a teaching credential:
I also like public schools because there are certified teachers and in-what's the name of the schools? Charter? There are children there that only have high school diplomas.

That's bad, the teachers need to be certified.

Parents also identified the lack of transportation as a factor impacting student attendance and absenteeism. Although many Detroit neighborhood public schools have been closed, there is no public transportation or school bus service to transport children from home to schools outside of the neighborhood. According to a mother of a public elementary school student, this results in the schools being "so far from where a lot of people stay at, by them closing so many." For parents with limited mobility and/or those who are employed outside the home, the lack of transportation for children acts as a significant barrier for educational attainment. For example, one parent of a child at a public elementary school said

I would like transportation for kids to tutoring. I have a problem with my leg, and it's days that she misses because I don't really have the support system as far as getting her here.

Similarly, parents with children in charter or private schools struggle with transportation issues because those schools usually do not provide transportation for students. Therefore, parents must either live close to those schools or have the ability to transport their children to and from school each day.

When parents expressed concern for their children's safety, they identified transportation problems as an important factor that makes it less safe for students to travel to and from school. One parent of a student at a public school spoke about how walking through surrounding neighborhoods is unsafe:

They're not thinking about, transportation-wise, they're not thinking about the neighborhoods that these kids have to deal with walking through, and it's dark. These are babies!

Another parent of an elementary school child mentioned that if the weather is bad (as it often is in Michigan winters), it is not always safe for children to walk to school. While parents want to send their children to school every day, some noted that there are days when it seems to make more sense to keep them home from school if there is no safe transportation option available.

Safety inside the school building was a concern for parents with children, particularly those with disabilities receiving special education services. A parent whose children attend a predominately Latino private school described how, as part of her job, she "visited many special education classes in Detroit Public Schools and ... if [she] had a child with a disability, [she] would also have a hard time leaving them there." Her job also allowed her to talk with parents who live in Detroit and have a child with a disability. She reported that they do not feel comfortable leaving their child in special education programs in public schools. In contrast, the mother of a student in the EAA school described feeling encouraged by her daughter's teachers and their teaching style.

Violence at school was also named by parents as a factor impacting the quality of a school's learning environment. One mother of a student attending an EAA high school was concerned that the school was overpopulated and had only four security guards. In response, another parent shared how her daughter "was always thinking someone was going to jump her so she used to carry a lock and all that and I started dropping her off and picking her up." Parents associated security guards with safety inside the school. They also touched on the importance of having a feeling or sense of safety while in school. One parent chose to send her children to a charter school because, when she used to drop her children off at the neighborhood public school, she had "seen children hitting other children, with teachers present in the hallway. Even though that [public] school is close to [her] house, [she] prefers to drive a little further" to bring her children to the charter school. 
Economic investment is required to secure adequate materials, teachers, and transportation services-investments that contribute to students' safety in school settings-and that ultimately shape their children's ability to learn, regardless of the type of school their children attended. One mother described transferring her son from a public to a private school because "he wasn't learning." At his new school, "there were fewer children" in his class, resulting in a learning environment consisting of "attention and care so that everyone is doing what they're supposed to be doing: their work."

While parents perceived economic investments as necessary to create quality learning environments, they also discussed the importance of school values, rules, and structure. As one parent of a student in a charter school said, "I don't send my son to public school, not because they are bad, but this school has rules. And when there are rules, the students learn respect." Likewise, parents at the private Catholic elementary school discussed the importance of Catholic values being a part of their children's education. Other parents described structures in place in certain public schools that create opportunities, such as scholarship programs for college. Some shared that they felt positive education outcomes depend in part on individual student attributes. As one mother noted,

I don't have anything against public schools or that others might be better, even though that might be true, but to me, a public school provides many opportunities, too. From my perspective, it has to do with the student's aptitude and capacity for development. The same is true for the teachers, but to me the public schools are good for me. And I see that my son is progressing very much.

The fit between school values, learning environment, student, and family matters to parents regardless of what type of school their children attend.

Overall, parents believed that economic investment in existing schools is more strategic than opening new schools in terms of improving education in Detroit. As one parent said,

Instead of opening so many new schools, they should focus on trying to achieve providing better education in the existing schools and improve their levels of education. Instead of handing out money to those new schools, they should invest in the existing ones to be able to provide a better education for our children.

Another parent of a child attending a public elementary school asked, "Why don't they invest more money in children's education, knowing that, if they receive better education, Detroit will be better or what it was like before, you know?"

\subsection{Access to trustworthy budget information}

The respondents in our sample did not believe that they were provided with accurate and trustworthy information, particularly in relation to budgets and spending. In several cases, parents expressed skepticism that the grim financial picture painted by state and district leaders is accurate. One respondent in the EAA focus group said, "I mean, the schools to me should not be in any kind of trouble because they're getting money from the lottery and they're getting money from the casinos." Another from the other EAA focus group told us "we would like to know where is the lottery money going for the schools [when there isn't] enough equipment or supplies for the schools for the kids."

Many suggested that, if there are indeed deficits, they are likely a consequence of political leaders or school official who steal from the school system. A parent with children in a public elementary school stated, "everybody's stealing money-principals-everybody's doing bad really. I can't really say what I want to say talking on this thing but it's really, really bad. And all our kids, with the exception of a few-the masses are losing out and the future is looking vague." One parent at an EAA high school suggested that corruption increased after the district "got rid of all the older teachers that really cared about the kids and not a paycheck. ... That's when they started stealing the money and everything." These leaders were perceived as profiting at the expense of Detroit children.

Because respondents were not convinced that they had accurate information about budgetary decisions or spending within the district, they were frustrated by policies that required cuts to spending. For example, one parent with children in a public elementary school critiqued emergency management:

It's good to have several people that agree to benefit everyone, not just themselves. Because [the emergency managers] are going to make decisions for their own benefit, to save money, because they aren't paying a fair salary to people who are performing. It's the money that will guide them-Ah-ha! They want to save money.

While nearly all the respondents either remained silent when asked about emergency management or critiqued the policy, it should be noted that one respondent whose children attended a private school supported it. This respondent suggested that bringing in an outsider to lead DPS made it more likely that the district could determine "what's going on with that financial situation," which she stated was particularly important because of its potential to end corruption within the district.

\subsection{Parent engagement and influence}

When respondents were asked about their previous experiences with school and classroom participation, many identified informal ways to support school administrators and teachers. As one parent from the charter school focus group said,

The school can't be responsible for everything. As parents, we also bear the responsibility, so if I want my daughter to be successful, I have to get involved in meetings and look out for the needs that exist. As parents, we need to inform the principal. Like they always say, four eyes see better than two.

This same respondent suggested that parent engagement helps children because "our time has already passed, but we have to be an example for our children, so that they improve. And this helps the school." However, parents struggled to identify instances in which they could secure formal roles within schools. One mother, also from the charter school group, told her peers, "I asked if I could participate as a volunteer and if I could help in any way, and I left my phone number ... but they never called me." To resolve this problem, she suggested that a volunteer calendar would help because "if it's planned out, it's possible to [volunteer], but I think that both parents and the teachers have to work on those things."

When parents were asked about their experiences with political or community engagement relating to schools, many referenced their support of teachers who acted collectively. For example, two respondents in the charter school focus group described how mothers at another nearby charter school supported teachers who were on strike:

(Respondent 1): When the teachers say, 'support us because we have to protest someplace,' we have to go support [them]. I don't agree with what's happening because it's our children's education. We care-at least I do.

(Respondent 2): I was going to say the same thing. The mothers at [the school] collected many signatures, I think, to not get rid of the teachers.

Similarly, when public school teachers engaged in widespread sickouts to protest school conditions and threats to their pay, many of the parents from the EAA group expressed support:

(Respondent 1): I had my daughter in [public school] and teachers were striking and striking and striking. I took her out during that 
time.

(Respondent 2): We got to protest. I guess we have to protest.

However, none of the participants reported examples of organizing as parents to influence school or district policies such as emergency management or the EAA.

When asked about barriers that they experienced in terms of political or community engagement, some parents attributed their lack of participation to the logistics of meetings. As one parent from a public elementary school said, "We all want to be heard, at least that's what the majority of us want-to be heard and counted. But for whatever reason, timing, work, whatever, sometimes we just can't do it." Another suggested that, if schools genuinely seek to engage with Spanishspeaking parents, then it is necessary to provide adequate translation services.

Within the EAA focus group, many parents expressed strong opposition to emergency management and the EAA. When asked if or how they have tried to influence these policies, a parent responded, "I actually went to all the meetings, but there's no way to resist-you just get to speak your mind just like we're doing right now. In the end, they do what they want." Another respondent agreed: "We voiced our opinion at meetings several times ... but we had no power. And especially since the school board had no power, we didn't have any power too. We could voice our opinions, but nothing was changed."

Other parents stated that they did not try to participate or influence decisions because they felt powerless. In a predominately African American public elementary school, a parent explained that her sense of powerlessness was the result of her participation within a statewide ballot initiative to repeal the emergency management law. At that time, signatures were collected throughout Michigan to put the law up for a ballot vote and, in the general election of 2012, the emergency management law was repealed by popular vote (Bowman, 2013). However, five weeks after Public Act 4 was repealed by voters, the state legislature passed a new bill that retained the same model of governance. This parent explained:

We went down there and signed a petition-they still had Emergency Management.. .. So I'm saying, we're doing all this-is it really gonna help us? Because we signed thousands and thousands of petitions, and he still got to manage the things.

An exception to the feeling of powerlessness was noted within a public school where students are predominately Latino. A respondent told us:

We know, the parents committee, we know that in other schools the opinions of the parents don't count. And with an Emergency Manager we know that as parents, our opinions are not going to count. ... We aren't going to be heard, we aren't going to be able to say that our children are behind others. ... [At our school, though, parents] can verify that our teachers are qualified, but I know that that's not possible on other schools. They put whoever they want, just to fill a position.

In this case, although parents were satisfied with their school's teachers, they noted that their opinions would not matter if there was a problem because of the emergency management system.

\subsection{Contentious relationships and a lack of trust}

As described, parents in the focus groups perceived that (1) Detroit Public Schools is able to provide fewer educational resources to students than those attending private or suburban schools, (2) state and district leaders misrepresent the degree of financial strain and make decisions on the basis of saving money rather than benefiting children, and (3) there were few formal opportunities for parents to participate and influence decisions within schools. This combination of perceptions culminated in what were often described as contentious relationships between parents and educational policy-makers. These contentious relationships were characterized as exhibiting a lack of trust. Parents did not trust state or district officials and they suggested that policy-makers did not trust them to provide adequate educational environments for their children. In this final section, we summarize how parents described their relationships with and perceptions of district and state policy-makers.

The lack of trust and cooperation was experienced by parents-particularly those whose children attended DPS or EAA schools-in their relationships with school administrators and district leaders. In some cases, they felt that leaders did not give parents the benefit of the doubt, perhaps because these leaders assumed that parents did not really care about the education of their children. One parent, whose child had been truant several times, tried to explain:

Now, my feet swell up. I have heart problems as well. Sometimes I can't put on shoes, and [school administrators] wanna make it about, "Oh, well, you know, you just need to get her here." How? How? Believe me, I want my child to succeed! Don't come to me and act like I just chose not to take her, because if I just didn't wanna take her, I wouldn't have to tell you anything, I would just not have her show up, you know?

In this case, both the parent and the school officials wanted the daughter to attend school, but the mother felt that she was being blamed for circumstances she could not control. In other cases, parents felt that they were being stereotyped because they were poor and Black or Latino. As one respondent said, "Just because [parents] are Hispanic doesn't mean that they don't have the capacity... we want for our children to have a higher level of education in Detroit. [Administrators] need to believe in us, they need to believe in our children." Another said, "The ones who decide everything in the district and those who are in government, they need to realize that in Detroit there are many welleducated children who wish to continue learning. They think that in the Detroit area, people are poor so they aren't going to study. No! There are many children who want to study, but if there isn't enough education, how will they ever get ahead?" In contrast, the parents whose children attend a private religious school were inclined to trust and view themselves as complementing school administrators, in part because of shared values.

Finally, parents stated that they did not trust decisions makers who do not have to live with the direct consequences of their decisions. One Latina mother, whose child attends a public elementary school, asked: "Why don't they choose someone who has their children in the schools?" This dynamic was viewed as particularly problematic when decisions were made without the input of stakeholders. Another woman in the same group said, “[emergency managers] don't ask opinions from other people, from parents, from teachers. .. but in my opinion, that's not such a good thing. It's good to have several people that agree to benefit everyone, not just themselves." This lack of information and stakeholder input was perceived as contributing to policies that harmed children and their education. A mother in the charter school group said

I think that that the only one who benefits [from emergency management] is the person who is in charge of the schools. The rest of the schools are on the fringes because no one knows what needs the school might have and each school needs different things-they may have autistic students or they may have advanced students. ... I think that placing one person in charge of all the schools is stupid because one person doesn't know what's needed. They know what they need, but not what the people need or what the schools need. And the public schools usually lack a gymnasium, classrooms, heat-they lack many things that that person doesn't because they have everything in their home, but they don't know what the schools need.

They attributed this flawed decision-making process, coupled with negative stereotypes about parents, as contributing to poor decisions 
and a lack of quality education in the city.

\section{Discussion}

The issues related to educational inequities and their disproportionate impact on the educational outcomes of low-income youth of color are well documented (Aud et al., 2011; Darling-Hammond, 1998). This study provides a unique perspective from which to view these issues, focusing on how parents (specifically, mothers) perceived, managed, and interacted with the educational system during a time of fiscal crisis, when many neighborhood schools were being closed and some public schools were no longer under local school board control. Examining these perceptions may help to inform the nature of education reform, as well as help to explain continued declines in public school enrollment. Additionally, parent voices may provide insight into how policy makers can implement changes to reverse such trends.

One of the recurrent themes within the focus groups was that parents were concerned about scarcity of educational resources, which they viewed as a contributing factor to the lack of safety, cleanliness, and overall school quality in local schools. Their calls to increase public spending and resources were particularly noteworthy in a context of urban austerity in which the emergency manager was required to cut spending in order to balance the budget. This finding suggests that, at least from the perspective of these parents, neoliberal school reforms including emergency management and the EAA do not adequately provide quality educational choices nor do they resolve long-standing inequalities caused by decades of population loss, racial and class segregation, and the decline of Detroit's tax base (Hula et al., 1997; Mirel et al., 1999). In the absence of more comprehensive policies to address underlying social inequalities, emergency management laws are unlikely to be successful in improving access to consistent quality public education, rates of truancy, nor public school enrollment in Detroit.

The focus group respondents also expressed a desire to participate in their children's school and to support teachers. However, when asked about their access to and opportunities for involvement in schools, mothers identified few formal opportunities and questioned their ability to access reliable information, particularly relating to school and district-wide budgets. Furthermore, mothers expressed support of teachers' collective political action, but described feelings of powerlessness in influencing policy at the district or school level. The perceptions of limited resources coupled with few opportunities for participation may have contributed to respondents' feelings that relationships between parents and school administrators are adversarial.

\subsection{Policy implications}

From the standpoint of school reform, it could be beneficial to prioritize opportunities for parents to access accurate information in a timely fashion and to influence decisions, including those relating to spending. Previous research about emergency management has noted that the policy undermines local democracy by suspending local representation, effectively limiting citizens' abilities to assert their political claims (Anderson, 2012; Loh, 2016; Lee et al., 2016). When parents were asked about emergency management as it relates to schools (e.g., the EAA and takeover of the Detroit School Board), they voiced suspicion relating to educational policy reforms in Michigan and the United States-particularly when those reforms did not include a change in educational funding. Additionally, parents identified few opportunities to challenge these policies. Instead, within a neoliberal context, their best options were viewed to be individual-level strategies (e.g., to personally drive children to school or enroll them in another district) rather than collective strategies. These perceptions are logical within a neoliberal context that engages parents as consumers as opposed to decision makers.

\subsection{Study limitations and directions for future research}

The goal of this study was to examine parents' perceptions of schools, parent participation, and educational reform in a context of urban austerity. As noted in the study methods, we used a purposive sampling strategy in order to (1) capture the voices of parents at three different types of schools and (2) engage parents whose children attend schools with predominantly African American and Latino student populations. That said, our sample is highly selective and the opinions of group participants is not necessarily representative of the majority of Detroit parents-nor parents whose children attend school in cities experiencing urban austerity measures. Future research should examine parent perceptions in other contexts. Additionally, we did not intend to make comparisons by school type nor ethnicity among our respondents due to our small sample size. Future research might examine how parent groups experience educational reforms differently on the basis of school type and race or ethnicity.

Additionally, because our recruitment strategy was to recruit the members of parent groups in each of the schools, it is probable that the parents knew one another and that they are more involved in their children's school as compared with other parents. It is likely that we captured the voices of the most highly involved parents and those with the resources to attend a focus group at their children's school. Future research should engage the voices of all caregivers, including parents who are not already part of parent groups. Additionally, because the respondents likely knew each other, there is potential for social desirability bias. Specifically, respondents may have hesitated to voice opinions that were not consistent with those of the majority. To help counter this, throughout our analysis we were careful to note dissenting opinions and to report those in the results section.

A final limitation was that we intentionally did not limit the size of the focus groups and decided to be as inclusive as possible. As a result, in some cases, the groups were quite large. Wibeck, Dahlgren, and Oberg (2007) recommend that focus groups include no more than eight people yet, in the current study, one of our focus groups consisted of eighteen people. Consequently, in this larger group, we likely missed opportunities to facilitate crosstalk between parents, to ask follow up questions, or to engage some of the quieter group members.

\section{Conclusion}

Research about educational policies and their impact on students and parents are of increased urgency in light of national debates about how to reform education in the United States. Detroit provides an important context to assess these reforms, given its struggle to provide consistent quality education in a context of population loss, racial and class segregation, and a declining tax base. Additionally, it has been home to neoliberal educational reforms that have been suggested as models for national policies. This study suggests the mothers of school children in Detroit were doubtful that policies emphasizing marketbased solutions and implemented without local influence should be considered as a model for national educational reforms. Rather, they suggest the need for increased educational resources, local leadership, and pathways for the meaningful inclusion of parent voices.

\section{Conflicts of interest}

None.

\section{References}

Anderson, M. W. (2012). Democratic dissolution: Radical experimentation in state takeovers of local governments. Fordham Urban Law Journal, 39, 577-623. http:// scholarship.law.berkeley.edu/facpubs/1943/, Accessed date: 15 October 2015.

Aud, S., Hussar, W., Kena, G., Bianco, K., Frohlich, L., Kemp, J., \& Tahan, K. (2011). The condition of education 2011 (NCES 2011-033). U.S. Department of Education, National Center for Education Statistics. 
Bomey, N., \& Gallagher, J. (2013, September 15). How Detroit went broke. Detroit Free Press1A.

Bowman, K. L. (2013). State takeovers of school districts and related litigation: Michigan as a case study. [Research paper no. 11-13]. The Urban Lawyer, 45, 1-19.

Burns, N. (1994). The formation of American local governments: Private values in public institutions. Oxford, England: Oxford University Press.

Census Reporter (2015). Race and ethnicity [Illustration of race and ethnicity population percentages from 2015 American Community Survey data for Detroit, MI]. https:// censusreporter.org/profiles/16000US2622000-detroit-mi/Accessed, Accessed date: 1 August 2017.

Center on Society and Health (2014). Why education matters to health: Exploring the causes. http://societyhealth.vcu.edu/work/the-projects/, Accessed date: 1 August 2017.

Darden, J. T., Stokes, C., \& Thomas, R. (2007). The state of black Michigan, 1967-2007. East Lansing: Michigan State University Press.

Darling-Hammond, L. (1998). Unequal opportunity: Race and education. Brookings Review, 16(2), 28-32.

DeVito, L. (2016, January 14). Detroit teachers are using Twitter to document poor school conditions. Detroit Metro Timeshttps://www.metrotimes.com/news-hits/archives/ 2016/01/14/detroit-teachers-are-using-twitter-to-document-poor-school-conditions/ , Accessed date: 29 June 2017.

Emerson, R. M., Fretz, R. I., \& Shaw, L. L. (2011). Writing ethnographic fieldnotes. Chicago: University of Chicago Press.

Hamlin, D. (2017). Parent involvement in high choice deindustrialized cities: A comparison of charter and public schools in Detroit. Urban Education, 1-29 (004208591769720).

Hammer, P. (2011). Fate of the Detroit public schools: Governance, finance and competition. Journal of Law in Society, 13, 111-154.

Harvey, D. (2005). A brief history of neoliberalism. New York: International Publishers.

Higgins, L. (2017a). EAA's end returns schools to Detroit fold. http://www.freep.com/ story/news/education/2017/04/29/detroit-schools-education-achievementauthority/100278366/, Accessed date: 29 June 2017.

Higgins, L. (2017b). Eight ways new Detroit school leader will boost enrollment. Detroit Free Presshttp://www.freep.com/story/news/2017/05/17/eight-ways-new-detroitschools-leader-boost-enrollment/325547001/, Accessed date: 29 June 2017.

Hula, R. C., Jelier, R. W., \& Schauer, M. (1997). Making education reform: Hard times in Detroit 1988-1995. Urban Education, 32, 202-232.

Lee, V. E., Croninger, R. G., \& Smith, J. B. (1994). Parental choice of schools and social stratification in education: The paradox of Detroit. Education Evaluation and Policy Analysis, 16, 434-457.

Lee, S. J., Krings, A., Rose, S., Dover, K., Ayoub, J., \& Salman, F. (2016). Racial inequality and the implementation of emergency management laws in economically distressed urban areas. Children and Youth Services Review, 70, 1-7.

Loh, C. G. (2016). The everyday emergency planning and democracy under austerity regimes. Urban Affairs Review, 52(5), 832-863.

Macedo, S. (2003). School reform and equal opportunity in America's geography of inequality. Perspectives on Politics, 1, 743-755.

Michigan Department of Education (2016). 2015-16 Accountability results school rankings and scorecard ratings [Data file]. http://www.michigan.gov/documents/mde/ 2015-16_Accountability_Results_List_for_Print_549027_7.pdf/, Accessed date: 29 June 2017.

Mirel, J., Galston, W., \& Guthrie, J. (1999). Urban public schools in the twentieth century: The view from Detroit. Brookings Papers on Education Policy, 2, 9-66.

National Assessment of Educational Progress (2015). Detroit district comparisons. https://www.nationsreportcard.gov/profiles/districtprofile/overview/XR?cti = PgTab_ScoreComparisons\&chort $=1 \&$ sub $=$ MAT\&sj $=$ XR\&fs $=$ Grade\&st $=$ MN\& year $=2015 \mathrm{R} 3 \& s g=$ Gender$\% 3 \mathrm{~A}+$ Male + vs. + Female $\& s g v=$ Difference\&ts $=$ Single + Year\&tss $=2015 R 3-2015 R 3 \& s f j=$ NL/, Accessed date: 29 June 2017.

National Allicance for Public Charter Schools (Nov 2015). A growing movement: America's largest charter school communities. P.3 http://www.publiccharters.org/ sites/default/files/migrated/wp-content/uploads/2015/11/enrollmentshare_web. pdf, Accessed date: June 2017.

Nygreen, K. (2016). Competing paradigms of educational justice: Parent organizing for educational equity in a neoliberal reform context. Equity \& Excellence in Education, 49, 202-214.

Peck, J. (2012). Austerity urbanism: American cities under extreme economy. City, 16, 626-655.

Pérez-Peña, R. (2016, January 11). 'Sickout' by Detroit teachers closes most public schools. The New York Timeshttps://www.nytimes.com/2016/01/12/us/sickout-by-detroitteachers-closes-most-public-schools.html? smid = tw-nytnational\&smtyp = cur / (Retrieved (add date)).

Reed, D. S. (2001). On equal terms: The constitutional politics of educational opportunity. Princeton, NJ: Princeton University Press.

Scorsone, E. A. (2014). Municipal fiscal emergency laws: Background and guide to statebased approaches. Working paper no. 14-21Arlington, VA: Mercatus Center at George Mason Universityhttp://mercatus.org/sites/default/files/Scorsone-Municipal-FiscalEmergency.pdf/, Accessed date: 2 October 2015.

Strauss, V. (2016, January 20). How bad are conditions in Detroit public schools? This appalling. Washington Posthttps://www.washingtonpost.com/news/answer-sheet/wp/ 2016/01/20/how-appalling-are-conditions-in-detroit-public-schools-this-appalling/? utm term $=$.dddb37094589/, Accessed date: 29 June 2017.

Sugrue, T. (2005). The origins of the urban crisis: Race and inequality in postwar Detroit. Princeton, NJ: Princeton University Press.

Wibeck, M., Dahlgren, M. A., \& Oberg, G. (2007). Learning in focus groups: An analytical dimension for enhancing focus group research. Qualitative Research, 7, 249-267.

Zaniewski, A. (2015, July 2). After 6 years of state control, DPS deficit skyrockets. Detroit Free Presshttps://www.freep.com/story/news/local/michigan/detroit/2015/07/02/ detroit-public-schools-deficit-spikes/29620019/, Accessed date: 7 March 2018. 